\title{
Effect of Capital Management on the Performance of Private Commercial Banks in Rwanda: A Case Study of Bank of Kigali
}

\author{
Sazir Nsubuga Mayanja ${ }^{1,}$, Kato Mahazi $^{1}$, Twesige Daniel ${ }^{2}$ \\ ${ }^{1}$ School of Post Graduate Studies, University of Kigali, Kigali, Rwanda \\ ${ }^{2}$ School of Business, INES-Ruhengeri, Ruhengeri, Rwanda
}

Email address:

saznsumay@gmail.com (S. N. Mayanja)

${ }^{*}$ Corresponding author

To cite this article:

Sazir Nsubuga Mayanja, Kato Mahazi, Twesige Daniel. Effect of Capital Management on the Performance of Private Commercial Banks in Rwanda: A Case Study of Bank of Kigali. Science Journal of Business and Management. Special Issue: Business Policy \& Strategic Management. Vol. 8, No. 3, 2020, pp. 132-140. doi: 10.11648/j.sjbm.20200803.14

Received: September 7, 2019; Accepted: October 15, 2019; Published: July 22, 2020

\begin{abstract}
The study was about capital management and performance of the banking sector with Bank of Kigali as the case study. The study was motivated by the various episodes of private bank failures in many parts of the world. This study therefore, examined the role of capital management on the performance of banking sector. To achieve, this objective, the following specific objectives guided this study: To explore the capital management techniques used by bank of Kigali; To examine the level of performance of Bank of Kigali To analyse a relationship between capital management and performance of the bank of Kigali and to examine challenges in the capital management and solution to the mentioned challenges. A multimethod approach composed of both qualitative and quantitative research design was used. Data was collected from both primary and secondary sources using questionnaire and documentation were used. A population comprised of 50 bank employees was selected, from which a sample of 32 respondents was determined using the Kreijcie and Morgan formula. Data was captured using the statistical package for sciences (SPSS) and presented into frequency tables. A regression analysis was carried out using SPSS. A significance test $\mathrm{t} \leq 5 \%$ was assumed. The findings indicated that a variation of $70.8 \%, 42 \%, 63 \%$, $71.6 \%$ and $64 \%$ in the capital adequacy, asset quality, management efficiency, earnings and liquidity of the bank is caused by capital management and other variables. More still, the findings from the survey indicated that the bank encounters a number of challenges which include, but not limited to capital modelling, quantification of risks and interpretation Basing on the results the study concluded that capital management is a key component in the performance management of the banking sector. The study suggested the following policies for the effective performance management of the bank; establishing the internal capital assessment process committee, capital buffers to cover the unexpected losses, use of stress and back-testing and active involvement of the board of directors in the capital management.
\end{abstract}

Keywords: Capital, Capital Management and Performance, Bank, Basel III, Banking Supervision, Risk

\section{Introduction}

Effective capital management is a core requirement of the banking sector. A bank that is under capitalised stands high risks of being liquidated since it cannot be able to protect the deposits of its customers [1]. Working capital management effectively influences the performance of commercial banks. Customer deposits, the size of the bank, outstanding expenditure and return on assets all have a positive impact on bank profitability and are statistically significant. Proper management is required in order to make good use of opportunities and minimize risks. Among the assets of a company we have working capital. Increasingly, research on how to increase profitability of firms, whether financial institutions or not, points at effective working capital management as being one of the important factors that determines the profitability [2]. During the early 1980's banks were not forced to keep a 
specific amount of equity. Exchange rates were fixed and banking was not as international as today. Sometimes this time in banking is referred to as 3-6-3-banking, meaning that in the morning the banker takes a loan at $3 \%$, he gives a loan at $6 \%$ and at $3 \mathrm{pm}$ he is on the golf course [3]. But that all changed in the early 1970's. Back then, the Bretton Woods pact, established in 1944, was abandoned.

In order to avoid insolvency a bank needs to hold a certain amount of capital to cover its unexpected losses and changes in asset values. This required capital can be divided into economic and regulatory capital.

\section{Literature Review}

Economic capital can be defined as the methods or practices that allow banks to consistently assess risk and attribute capital to cover the economic effects of risktaking activities. Originally developed by banks as a tool for capital allocation and performance assessment, its use has been extended to applications that require accuracy in estimation of the level of capital (or risk), such as the quantification of the absolute level of internal capital needed by a bank.[4] Regulatory capital is the capital required by the national supervisory and multilateral authorities to protect the banking system and its depositors, thus the

(Basel Committee on Banking Supervision) issued Basel III in December 2010 and revised it in June 2011, after the global banking crisis to enhance the Basel framework and strengthen the three pillars that were established by Basel II (Basel Committee on Banking Supervision BCBS). The revised framework (Basel III) also introduced several regulatory capital innovations and it established new minimum common equity and Tier 1 requirements and added an additional layer of common equity (the capital conservation buffer), a countercyclical buffer, a leverage ratio (based on both a bank's onbalance-sheet assets and off-balance-sheet exposures

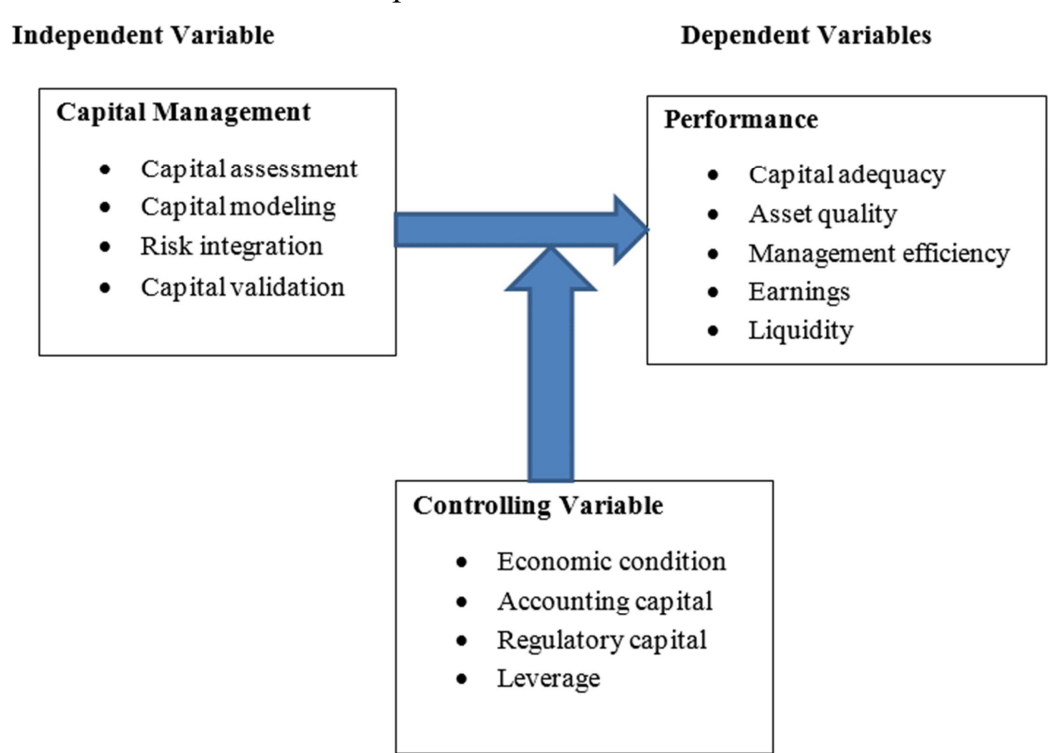

regardless of risk weighting), and supplementary capital requirements for systemically important banks. [5]

The variables input as necessary under Basel III to compute capital that complies with the regulatory requirements makes it not only tedious but also complex. For example, banks may respond differently to capital requirements depending on differences in both the level of existing capital and the composition of the existing components of that capital.[6]

The various crises that have been witnessed in the global financial system have challenged the best of economic minds, policy makers at national level and multilateral agencies like the IMF, the IBRD and their affiliates. For example, following the Latin American Debt Crisis of 1982, the Asian Tiger financial crisis and most recently the 2007-2009 crisis, which started merely as United States of America issue but became global, predictable reaction has been to raise minimum capital standards in the hope that this will promote stable banking systems. Unfortunately, this has still not prevented periodic the disruptive economic phenomenon to occur, and worse still, with increasing intensity and complexity. Ironically during the 2007-2009 crisis some financial institutions were deemed to be too big to fail, but in need of assistance.

This study examines the role of the performance of the banking sector in Rwanda in light of capital requirements.

\subsection{Conceptual and Theoretical Framework of Analysis}

A conceptual framework is a structure which describes the relationship between the main concepts of a study to facilitate the researcher's explanation of how the research problem would be explored and it is therefore arranged in a logical structure to aid provide a picture or visual display of how ideas in a study relate to one another [7]

This section shows the relationships between the variables.

\section{Dependent Variables}


Capital management through capital assessment, capital modelling, risks integration and capital validation has a direct effect on the capital adequacy, asset quality, management efficiency, earnings and the liquidity of the bank. However, for the relationship to hold, the economic conditions, accounting capital, regulatory capital, and level of leverage and economic capital of the bank must be considered.

\subsection{Theoretical Framework of Analysis}

Banking Supervision introduced the Basel I capital accord in 1988. This accord aimed at enhancing the regulatory capital framework of commercial banks through calculation of market and credit risks. Due to inefficiencies in the Basel I Capital Accord, in 1998 Basel Committee on banking supervision (BCBS) introduced the Basel II Capital Accords. This accord is based on three pillars where pillar $I$ is about minimum capital requirements, pillar II about supervisory requirements and pillar III is about market discipline [8].

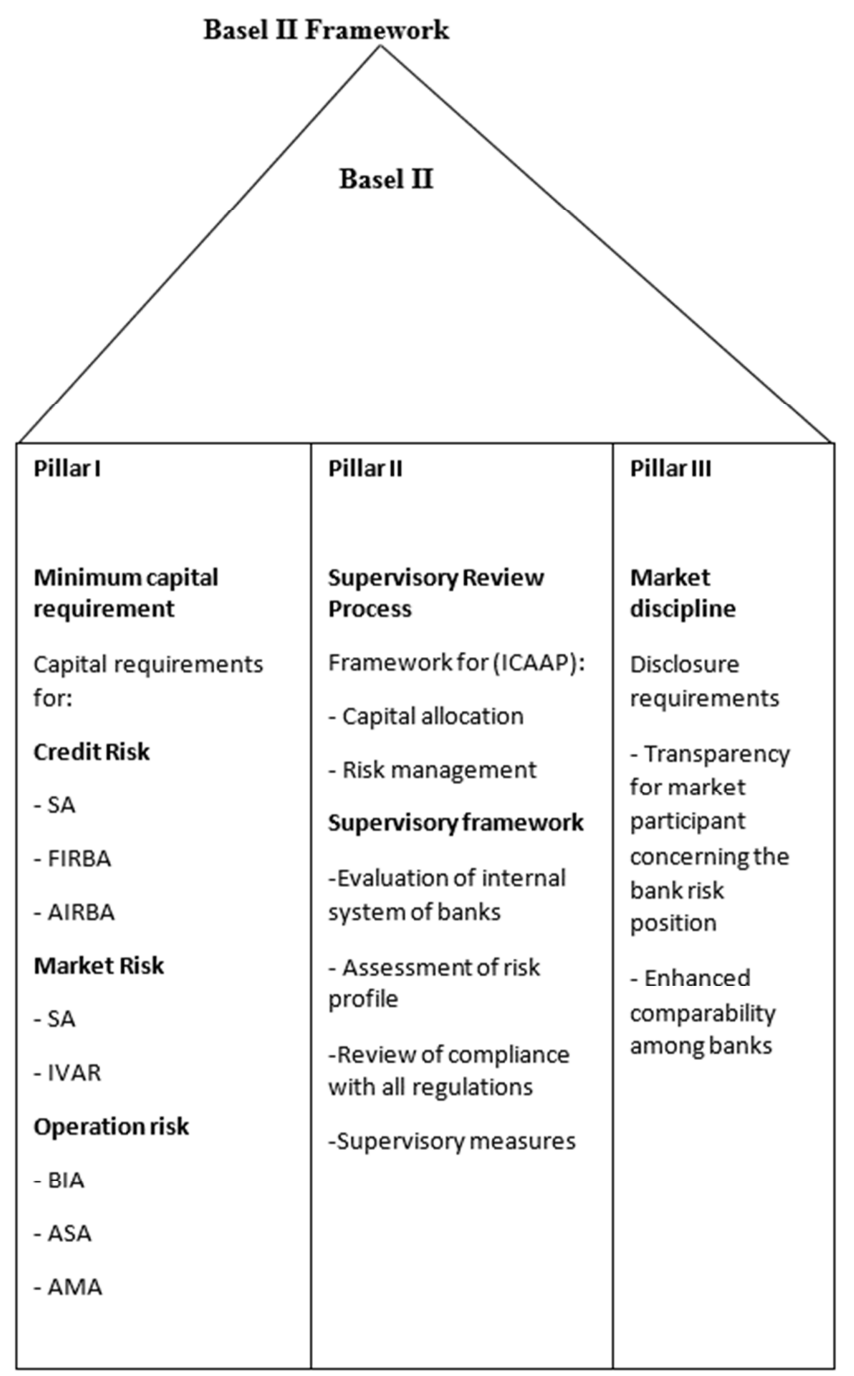

Figure 2. Basel II Capital Frameworks.
The first pillar provides new rules for setting minimum capital requirements on market, operational and credit risks [9]. The general requirement for banks within the Basel II rules is to "hold total capital equivalent to at least $8 \%$ of their risk weighted assets. The capital requirements are extended by operational risks in comparison to Basel I: Regulatory capital Risk weighted assets Credit Risk $+12.5 \%$ Requirements (Market Risk + Operational Risk) 8\% "Total risk weighted assets are determined by multiplying the capital requirements for market risk and operational risk by 12.5 and adding the resulting figures to the sum of risk weighted assets for credit risk" [10]. Basel II provides various approaches which banks can use to determine the minimum capital requirements. Pillar I of Basel II provides the following approaches for the determination of minimum capital for the banking institutions. The committee provides a Standardized Approach, which defines risk weights for the different groups of debtors based on external ratings. On the other hand, it provides the Internal Ratings Based Approach (IRB-Approach), which defines risk weights on the basis of internal measurements for credit, risks [11]. In contrast to the measurement of market risks, where the $\mathrm{VaR}$ is used both internally and externally, and to the measurement of the operational risks, where internally the Advanced Measurement Approach is frequently used, substantial differences between internal (VaR based) approaches and the regulatory approaches can be asserted particularly in the context of Basel II and credit risk measurement.[12]

A more sophisticated option is the Internal Ratings Based Approach (IRB-Approach) which comprises two possibilities: The Foundation Approach (FIRB) and the Advanced Approach (AIRB). In these approaches, banks use their own internal ratings on customers' creditworthiness to determine the minimum capital requirement set against exposure to the customer's credit risk. A bank implementing one of the IRB-Approaches has to estimate an average probability of default (PD) for customers belonging to a given internal rating category. This $\mathrm{PD}$, reflecting the credit risk of the exposure, is then used as an input parameter to the risk weight function provided by the Basel II-framework. The most advanced IRB-approach allows banks to use their internal risk models for the estimation of the parameters of the risk weight function (PD, Loss Given Default and Exposure at Default) to determine their minimum capital requirements. According to KPMG [13], Basel III now adds the following reforms: calculation of the capital requirements for counterparty credit risk (CCR) based on stressed inputs; introduction of a capital charge for potential mark-to-market losses (that is credit valuation risk); strengthening standards for collateral management and initial margining; higher capital requirements for OTC derivatives exposures and raising CCR management standards.

In addition, Basel III introduces new liquidity standards to 
achieve two objectives. The first objective, pursued by the Liquidity Coverage Ratio (LCR), is to promote short-term resilience of a bank's liquidity risk profile by ensuring that it has sufficient high quality liquid assets to survive a stress scenario lasting one month. The second objective is to promote resilience over the longer term by creating additional incentives for a bank to fund its activities with more stable sources of funding. The Net Stable Funding Ratio (NSFR), with a time horizon of one year, should provide a sustainable maturity structure of assets and liabilities [14].

According to BCBS [15], Basel III provides new a definition to capital which comprises the following elements: Going-concern capital (Tier 1 capital); Common Equity Tier 1 capital (CET 1 capital): Common equity (that is, common shares and retained earnings) must be the predominant form of Tier 1 capital. Basel III introduces the following percentage of risk-weighted assets, RWA: total capital ratio will remain $8 \%$ of RWA. CET 1 capital ratio increases from $2 \%$ to $4.5 \%$. Additional Tier 1 capital ratio is $1.5 \%$, leading to a Tier 1 capital ratio of $6 \%$. The importance of Tier 2 capital decreases by reducing the ratio to $2 \%$ of RWA. Apart from these changes, Basel III will introduce two new capital buffers: a capital conservation buffer of $2.5 \%$ and a countercyclical buffer of $0-2.5 \%$ depending on macroeconomic circumstances. The capital conservation buffer, $2.5 \%$ of RWA and to be met with CET 1 capital, applies at all times and it is intended to ensure that institutions are able to absorb losses in stress periods lasting for a number of years. Considering the $4.5 \%$ CET 1 capital ratio, institutions must hold $7.0 \%$ CET 1 capital on an individual and consolidated basis at all times.

Basel III also strengthens the requirements for the management and capitalization of counterparty credit risk (CCR). It includes an additional capital charge for possible losses associated with deterioration in the creditworthiness of counterparties or increased risk weights on exposures to large financial institutions. The new framework also enhances incentives for clearing over-the-counter (OTC) instruments through central counterparties (CCP). For banks using an Internal Model Method (IMM) to calculate the CCR regulatory capital, Basel III requires determining the default risk capital charge by using the greater of the portfolio-level capital charge (not including CVA charge) based on Effective Expected Positive Exposure (EEPE) using current market data and the one based on EEPE. The method uses stress calibration. The greater of the EEPEs should not be applied on a counterparty-by-counterparty basis, but on a total portfolio level [16]

In addition, to the default risk capital requirements for CCR, Basel III introduces an additional capital charge to cover the risk of mark-to-market losses on the expected counterparty risk (Credit Valuation Adjustment, CVA) to OTC derivatives. The calculation of the CVA charge depends on the method banks use to determine the capital charge for $\mathrm{CCR}$ and specific interest rate risk. Transactions with a central counterparty (CCP) and securities financing transactions (SFT) need not be considered. Banks with IMM approval for CCR risk and approval to use the market risk internal models' approach for the specific-interest rate risk of bonds must calculate the additional capital charge by modelling the impact of changes in the counterparty's credit spread on the CVAs of al OTC derivatives using the internal VaR model for bonds. This VaR model is restricted to changes in the counterparties' credit spreads and does not model the sensitivity of CVA to changes in other market factors. The method focuses on changes in the value of the reference asset, commodity, currency or interest rate of a derivative. The CVA risk capital charge consists of both general and specific credit spread risks, including Stressed VaR but excluding incremental risk charge (IRC). The Basle Committee on Banking Supervision of the Bank of International Settlements (BIS) has recommended using capital adequacy, assets quality, management quality, earnings and liquidity (CAMEL) as criteria for assessing the health of financial institutions in 1988. The sixth component, market risk (S) was added to CAMEL in 1998. The "CAMELS" ensures a bank's healthy conditions by reviewing different aspects of a bank based on a variety of information sources such as the financial statement, the funding sources, macroeconomic data, budget as well as cash flow.

\section{Methodology}

This section shows the methods and techniques that were employed during this study.

\subsection{Research Design}

The research design may be defined as the arrangement of conditions for collection, and analysis of data in a manner that aims to combine relevance research purposes with the economy in procedure [17]. The study design was based on a multi-method strategy which used both qualitative and quantitative research strategies.

\subsection{Study Population}

A study population is the set of all elements in the universe [18]. In this research, the study made a survey on 40 employees located at the head office. The researcher only targeted those employees that are acquainted with financial management.

\subsection{Sample Size and Procedures}

A sample size is the number of items to be selected from the universe to constitute a sample. In selecting a sample an optimum sample size was considered, that is one which fulfils the requirement of efficiency, representativeness, reliability and flexibility. The formula for determining a sample size of a known population size as Krejcie and Morgan [19] is given by: 


$$
n=\frac{x^{2} N P(1-P)}{d^{2}(n-1)+X^{2} P(1-P)}
$$

Where: $\mathrm{n}$ is the sample size, $\mathrm{X}^{2}$ is the Chi square, $\mathrm{N}$ is the total population size, $\mathrm{P}$ is probability of success and $\mathrm{d}^{2}$ is the degree of freedom. According to Krejcie \& Morgan [20], at the degree of freedom $\left(\mathrm{d}^{2}\right)$ of $1 \%(0.01)$, the Chi square $\left(\mathrm{X}^{2}\right)$ is 6.64 . The probability of success $(\mathrm{P})$ is $50 \%(0.5)$

Substituting in the formula:

$$
n=\frac{6.64 \times 40 \times 0.5(1-0.5)}{0.01 \times 39+6.64 \times 0.5 \times 0.5} \Rightarrow n=32
$$

The respondents within the selected population were selected purposively.

\subsection{Qualitative Data Collection}

In order to address the objectives of the study, primary data was collected by holding in-depth interviews using interview guide with financial institutions manager on their coverage. These in-depth interviews involved discussions between the researcher and the respondents on capital management and performance of banking sector.

\subsection{Quantitative Data Collection}

The quantitative data was collected using one sets of questionnaires that were given to the bank employees. The questionnaire will be designed using a five-point Likert scale, both closed and open-ended questions were used. Open ended questions were seeking the views of respondents on the subject matter. In this study the researcher used both the structured and the unstructured self-administered questionnaires, because it is relatively cheap. Furthermore, when the study involves identifying a relationship between variables, the questionnaires helps to get data that describe a relationship between different variables.

\subsection{Qualitative and Quantitative Data Analysis}

The survey data that was generated from the questionnaires was analysed using both exploratory and confirmatory statistical techniques. After receiving the completed questionnaires from the field, a data entry capture template was designed in the Statistical Package for Social Scientists (SPSS) which was used for data entry. After data entry and cleaning up, exploratory statistical data analysis was conducted using frequency distribution tables to summarise and display the respondents' views on the questions under study.

\subsection{Empirical Models}

Bank performance $(\mathrm{BP})=\mathrm{f}($ capital management $\mathrm{CM})$

$$
\mathrm{BP}=\beta_{0}+\beta_{1} \mathrm{CM}+\alpha
$$

But capital management $(\mathrm{CM})=\mathrm{f}$ (capital assessment (CA), risks integration (RI), capital modelling (MC) and capital validation $(\mathrm{CV})]$

$$
\mathrm{CM}=\beta 0+\beta 1 \mathrm{CA}+\beta 2 \mathrm{RI}+\beta 3 \mathrm{MC}+\beta 3 \mathrm{CV}+\alpha
$$

Substituting equation two into one

$$
\mathrm{BP}=\beta 0+\beta 1 \mathrm{CA}+\beta 2 \mathrm{RI}+\beta 3 \mathrm{MC}+\beta 3 \mathrm{CV}+\alpha
$$

Besides, capital management, bank performance can also be affected by other variables such economic conditions (CE), accounting capital (AC), regulatory capital (RC) and leverage (LV)

Therefore:

$$
\mathrm{BP}=\beta 0+\beta_{1} \mathrm{CA}+\beta_{2} \mathrm{RI}+\beta_{3} \mathrm{MC}+\beta_{4} \mathrm{CV}+\beta_{5} \mathrm{CE}+\beta_{6} \mathrm{AC}+\beta_{7} \mathrm{RC}+\beta_{8} \mathrm{LV}+\alpha
$$

But bank performance (BP) can be measured in terms of CAMEL which is defined as capital adequacy (CQ), asset quality (AQ), management efficiency (ME), earnings (E) and liquidity (L)

Therefore, substituting in (6);

$$
\begin{aligned}
& \mathrm{CQ}=\beta 0+\beta_{1} \mathrm{CA}+\beta_{2} \mathrm{RI}+\beta_{3} \mathrm{MC}+\beta_{4} \mathrm{CV}+\beta_{5} \mathrm{CE}+\beta_{6} \mathrm{AC}+\beta_{7} \mathrm{RC}+\beta_{8} \mathrm{LV}+\alpha \\
& \mathrm{AQ}=\beta 0+\beta_{1} \mathrm{CA}+\beta_{2} \mathrm{RI}+\beta_{3} \mathrm{MC}+\beta_{4} \mathrm{CV}+\beta_{5} \mathrm{CE}+\beta_{6} \mathrm{AC}+\beta_{7} \mathrm{RC}+\beta_{8} \mathrm{LV}+\alpha \\
& \mathrm{ME}=\beta 0+\beta_{1} \mathrm{CA}+\beta_{2} \mathrm{RI}+\beta_{3} \mathrm{MC}+\beta_{4} \mathrm{CV}+\beta_{5} \mathrm{CE}+\beta_{6} \mathrm{AC}+\beta_{7} \mathrm{RC}+\beta_{8} \mathrm{LV}+\alpha \\
& \mathrm{E}=\beta 0+\beta_{1} \mathrm{CA}+\beta_{2} \mathrm{RI}+\beta_{3} \mathrm{MC}+\beta_{4} \mathrm{CV}+\beta_{5} \mathrm{CE}+\beta_{6} \mathrm{AC}+\beta_{7} \mathrm{RC}+\beta_{8} \mathrm{LV}+\alpha . \\
& \mathrm{L}=\beta 0+\beta_{1} \mathrm{CA}+\beta_{2} \mathrm{RI}+\beta_{3} \mathrm{MC}+\beta_{4} \mathrm{CV}+\beta_{5} \mathrm{CE}+\beta_{6} \mathrm{AC}+\beta_{7} \mathrm{RC}+\beta_{8} \mathrm{LV}+\alpha
\end{aligned}
$$

\section{Results and Discussion}

Table 1. Determinants of Capital Adequacy in Bank of Kigali.

\begin{tabular}{lllll}
\hline Model & R & R Square & Adjusted R Square & Std. Error of the Estimate \\
\hline 1 & $.842^{\mathrm{a}}$ & .708 & .428 & 8.148 \\
\hline
\end{tabular}

a. Predictors: (Constant), level leverage, capital assessment risk integration, capital modelling, economic conditions, accounting capital, capital validation, regulatory capital 


\begin{tabular}{|c|c|c|c|c|c|c|}
\hline \multicolumn{7}{|c|}{ Coefficients $^{\mathrm{a}}$} \\
\hline \multirow{2}{*}{ Model } & & \multicolumn{2}{|c|}{ Unstandardized Coefficients } & \multirow{2}{*}{$\begin{array}{l}\text { Standardized Coefficients } \\
\text { Beta }\end{array}$} & \multirow{2}{*}{$\mathbf{t}$} & \multirow{2}{*}{ Sig. } \\
\hline & & B & Std. Error & & & \\
\hline \multirow{9}{*}{1} & (Constant) & 112.527 & 37.943 & & 2.966 & .007 \\
\hline & Capital assessment & -8.584 & 2.674 & -1.220 & -3.210 & .025 \\
\hline & Capital modelling & -9.253 & 3.606 & -.962 & -2.566 & .037 \\
\hline & Risk integration & -11.254 & 2.474 & -.017 & -4.548 & .000 \\
\hline & Capital validation & 4.506 & 3.463 & .236 & 1.301 & .206 \\
\hline & Economic conditions & 15.912 & 4.412 & .965 & 3.605 & .019 \\
\hline & Accounting capital & -4.955 & 4.900 & -.193 & -1.011 & .322 \\
\hline & Regulatory capital & -2.519 & 3.251 & -.180 & -.775 & .446 \\
\hline & Level leverage & -9.524 & 2.480 & -1.230 & -3.840 & .015 \\
\hline
\end{tabular}

a. Dependent Variable: capital adequacy

The results in table 1 above analyses the statistical significance of capital management, other variables and performance of banks as measured by the asset quality. The results from the survey showed that there is weak relationship between capital management, other variables and asset quality of the bank. The results as measured by
R-square and adjusted R- square show that of the total variation in the asset quality, $42.0 \%$ is caused by capital management process and other variables. The most significant factors to this relationship are capital modelling, risks integration and the regulatory capital. Therefore, the asset quality is:

$$
(A Q)=33.83-1.624 \mathrm{CA}+3.358 \mathrm{CM}+11.988 \mathrm{RI}+1.02 \mathrm{CV}+2.763 \mathrm{EC}+.386 \mathrm{AC}+23.311 \mathrm{RC}+3.265 \mathrm{~L}
$$

The results as measured by $\mathrm{R}$-square and adjusted Rsquare, show that $70.8 \%$ of the total variation in the capital adequacy is caused by capital management process and other variables. A statistical significance of the variables is considered were $\mathrm{t} \leq 5 \%$. The results indicated that there is negative relationship between capital assessment, capital modeling, risk integration and level of leverage and performance of the banking sector.

$$
\mathrm{CA}=112.527-8.584 \mathrm{CA}-9.253 \mathrm{CM}-11.254 \mathrm{RI}+4.506 \mathrm{CV}+15.912 \mathrm{EC}-4.955 \mathrm{AC}-2.519 \mathrm{RC}-9.524 \mathrm{~L}
$$

Table 2. Determinants of Asset Quality in BK.

\begin{tabular}{lllll}
\hline Model & R & R Square & Adjusted R Square & Std. Error of the Estimate \\
\hline 1 & $.653^{\mathrm{a}}$ & .420 & .371 & 12.046 \\
\hline
\end{tabular}

a. Predictors: (Constant), level leverage, capital assessment risk integration, capital modelling, economic conditions, accounting capital, capital validation,

\begin{tabular}{|c|c|c|c|c|c|c|}
\hline \multicolumn{7}{|c|}{ Coefficients $^{\mathrm{a}}$} \\
\hline \multirow{2}{*}{\multicolumn{2}{|c|}{ Model }} & \multicolumn{2}{|c|}{ Unstandardized Coefficients } & \multirow{2}{*}{$\begin{array}{l}\text { Standardized Coefficients } \\
\text { Beta }\end{array}$} & \multirow{2}{*}{$\mathbf{t}$} & \multirow{2}{*}{ Sig. } \\
\hline & & B & Std. Error & & & \\
\hline \multirow{9}{*}{1} & (Constant) & 33.832 & 13.762 & & 2.458 & .035 \\
\hline & Capital assessment & -1.624 & 3.789 & -.082 & -.429 & .672 \\
\hline & Capital modelling & 3.358 & 1.109 & .538 & 3.027 & .018 \\
\hline & Risk integration & -11.988 & 3.505 & -1.109 & -3.420 & .014 \\
\hline & Capital validation & 1.020 & 4.907 & .044 & .208 & .837 \\
\hline & Economic conditions & 2.763 & 6.252 & .102 & .442 & .663 \\
\hline & Accounting capital & .386 & 6.942 & .012 & .056 & .956 \\
\hline & Regulatory capital & 23.311 & 4.606 & 1.194 & 5.061 & .000 \\
\hline & Level leverage & 3.265 & 3.514 & .244 & .929 & .362 \\
\hline
\end{tabular}
regulatory capital

a. Dependent Variable: asset quality

Table 2 above shows the determinants of Asset Quality in BK. With risk integration and regulatory capital indicating the highest swings of beta factors of -1.109 and 1.194 respectively, among all of them.
The implication is that banks are risk sensitive and that supervisory authorities play a very important role in their operations, as they have the powers to licence or withdraw the licenses. 
Table 3. Determinants of Management Efficient in BK.

\begin{tabular}{lllll}
\hline Model & R & R Square & Adjusted R Square & Std. Error of the Estimate \\
\hline 1 & $.794^{\mathrm{a}}$ & .630 & .481 & 1.721 \\
\hline
\end{tabular}

a. Predictors: (Constant), level leverage, capital assessment risk integration, capital modelling, economic conditions, accounting capital, capital validation, regulatory capital

\begin{tabular}{|c|c|c|c|c|c|c|}
\hline \multicolumn{7}{|c|}{ Coefficients $^{\mathrm{a}}$} \\
\hline \multirow{2}{*}{\multicolumn{2}{|c|}{ Model }} & \multicolumn{2}{|c|}{ Unstandardized Coefficients } & \multirow{2}{*}{$\begin{array}{l}\text { Standardized } \\
\text { Coefficients } \\
\text { Beta }\end{array}$} & \multirow{2}{*}{$\mathrm{t}$} & \multirow{2}{*}{ Sig. } \\
\hline & & B & Std. Error & & & \\
\hline \multirow{9}{*}{1} & (Constant) & 37.067 & 5.208 & & 7.117 & .000 \\
\hline & Capital assessment & 8.607 & 3.539 & .375 & 2.432 & .023 \\
\hline & Capital modelling & 10.614 & 4.771 & .305 & 2.225 & .051 \\
\hline & Risk integration & -1.148 & 3.273 & -.054 & -.351 & .729 \\
\hline & Capital validation & 9.993 & 4.583 & .371 & 2.181 & .040 \\
\hline & Economic conditions & -1.326 & 5.839 & -.042 & -.227 & .822 \\
\hline & Accounting capital & -12.425 & 4.483 & -.543 & -2.772 & .048 \\
\hline & Regulatory capita & .176 & 4.302 & .009 & .041 & .968 \\
\hline & Level leverage & -2.298 & 3.282 & -.149 & -.700 & .491 \\
\hline
\end{tabular}

a. Dependent Variable: management efficiency

In table 3 above, show the predictors of management efficient. The results in the table above show that of the total variation in the management efficient $63 \%$ is caused by the predictors as indicated by the R-square. The most significant predictors as measured by the statistical $t$ are capital assessment, capital modelling and accounting capital.

$$
\mathrm{ME}=37.067+8.607 \mathrm{CA}+10.614 \mathrm{CM}-1.148 \mathrm{RI}+9.993 \mathrm{CV}-1.326 \mathrm{EC}-12.425 \mathrm{AC}+.176 \mathrm{RC}-2.298 \mathrm{~L}
$$

Table 4. Determinants of Earnings of $B K$

\begin{tabular}{lllll}
\hline Model & R & R Square & Adjusted R Square & Std. Error of the Estimate \\
\hline 1 & $.846^{\mathrm{a}}$ & .716 & .514 & 1.113 \\
\hline
\end{tabular}

a. Predictors: (Constant), level leverage, capital assessment risk integration, capital modelling, economic conditions, accounting capital, capital validation, regulatory capital

\begin{tabular}{|c|c|c|c|c|c|c|}
\hline \multicolumn{7}{|c|}{ Coefficients $^{\mathrm{a}}$} \\
\hline \multirow{2}{*}{\multicolumn{2}{|c|}{ Model }} & \multicolumn{2}{|c|}{ Unstandardized Coefficients } & \multirow{2}{*}{$\begin{array}{l}\text { Standardized Coefficients } \\
\text { Beta }\end{array}$} & \multirow{2}{*}{$\mathbf{t}$} & \multirow{2}{*}{ Sig. } \\
\hline & & B & Std. Error & & & \\
\hline \multirow{9}{*}{1} & (Constant) & 102.484 & 24.440 & & 4.193 & .000 \\
\hline & Capital assessment & -.015 & 1.723 & -.001 & -.008 & .993 \\
\hline & Capital modelling & -13.062 & 2.323 & -1.236 & -5.623 & .000 \\
\hline & Risk integration & -4.156 & 1.593 & -.426 & -3.484 & .020 \\
\hline & Capital validation & -2.521 & 2.231 & -.204 & -1.130 & .270 \\
\hline & Economic conditions & .935 & 2.842 & .065 & .329 & .745 \\
\hline & Accounting capital & 10.106 & 3.156 & 1.607 & 3.202 & .029 \\
\hline & Regulatory capital & 4.468 & 2.094 & .493 & 2.134 & .044 \\
\hline & Level leverage & -8.541 & 1.597 & -1.217 & -5.348 & .000 \\
\hline
\end{tabular}

a. Dependent Variable: earnings

The results in table 4 above, show the predictors of earnings of the banking sector. The results as measured by Rsquare showed that $71.6 \%$ of the total variation in earnings of the bank is caused by the capital management and other variables. This shows that there is a strong relationship

$$
\mathrm{E}=102.484-.015 \mathrm{CA}-13.062 \mathrm{CM}-4.156 \mathrm{RI}-2.521 \mathrm{CV}+.935 \mathrm{EC}+.10 .106 \mathrm{AC}+4.46811 \mathrm{RC}-8.541 \mathrm{~L}
$$


Table 5. Determinants of Liquidity of $B K$.

\begin{tabular}{lllll}
\hline Model & R & R Square & Adjusted R Square & Std. Error of the Estimate \\
\hline 1 & $.800^{\mathrm{a}}$ & .640 & .412 & 2.238 \\
\hline
\end{tabular}

a. Predictors: (Constant), level leverage, capital assessment risk integration, capital modelling, economic conditions, accounting capital, capital validation, regulatory capital

\begin{tabular}{|c|c|c|c|c|c|c|}
\hline \multicolumn{7}{|c|}{ Coefficients $^{\mathrm{a}}$} \\
\hline \multirow{2}{*}{\multicolumn{2}{|c|}{ Model }} & \multicolumn{2}{|c|}{ Unstandardized Coefficients } & \multirow{2}{*}{$\begin{array}{l}\text { Standardized Coefficients } \\
\text { Beta }\end{array}$} & \multirow{2}{*}{$\mathbf{T}$} & \multirow{2}{*}{ Sig. } \\
\hline & & B & Std. Error & & & \\
\hline \multirow{9}{*}{1} & (Constant) & 212.739 & 67.685 & & 3.143 & .005 \\
\hline & Capital assessment & -24.957 & 4.771 & -1.193 & -5.231 & .000 \\
\hline & Capital modelling & -3.990 & 6.432 & -.126 & -.620 & .541 \\
\hline & Risk integration & -.009 & 4.412 & .000 & -.002 & .998 \\
\hline & Capital validation & -16.152 & 6.178 & -.804 & -2.614 & .047 \\
\hline & Economic conditions & 1.326 & 7.871 & .038 & .168 & .868 \\
\hline & Accounting capital & -39.306 & 8.740 & -1.230 & -4.497 & .001 \\
\hline & Regulatory capital & -11.910 & 5.799 & -.538 & -2.054 & .052 \\
\hline & Level leverage & 13.005 & 4.424 & .674 & 2.939 & .040 \\
\hline
\end{tabular}

a. Dependent Variable: liquidity

Source: Survey Data 2016

Table 5 above analyses the effect of capital management, other variables and liquidity of the banking sector. The results from the survey as measured by $\mathrm{R}$-square and adjusted R-square indicated that $64 \%$ and $41.2 \%$ respectively of the total variation in the liquidity of the bank is caused by the predictors mentioned in the 4.5 above The results further indicated that capital assessment, capital validation, accounting capital, level of leverage and regulatory capital as the most significant factors in the relationship.

$$
\mathrm{L}=212.739-24.957 \mathrm{CA}-3.99 \mathrm{CM}-0.009 \mathrm{RI}-16.152 \mathrm{CV}+1.326 \mathrm{EC}-39.306 \mathrm{AC}-11.91 \mathrm{RC}+13.0055 \mathrm{~L}
$$

\section{Conclusion and Recommendations}

The performance of the bank is directly dependent upon its ability to evaluate, manage and price the risks encountered, while maintaining an adequate capitalisation and liquidity to meet unforeseen events. To secure the financial stability of the banking sector, risk and capital-related issues should be identified, monitored and managed at an early stage. This should form an integral part of the long term strategic and business planning process. The bank's capital policy should define how capital management should support the business goals. Shareholders' return requirements should be balanced against the capital requirements of the regulators, the expectations of debt investors, customers and other counterparties as regards the bank's rating, and the economic capital that represents the total risk of the bank. Scenario stress testing and back testing should be used to assess an extra safety margin over and above the formal capital model requirements covering for example the potential of a sharp decline in the macroeconomic environment.

Banks should establish committee for Internal Capital Adequacy Assessment Process (ICAAP) with the purpose to assess capital requirements in relation to the bank's risk profile, and to propose a strategy for maintaining the capital levels. This process should be integrated with the bank's business planning and should be part of the internal governance framework and the internal control system.
Together with continuous monitoring, and reporting of the capital adequacy to the Board, this will ensure that the relationships between shareholders' equity, economic capital, regulatory and rating-based requirements are managed in such a way that the bank does not jeopardise the profitability of the business and the financial strength of the industry.

Notwithstanding good risk management, banks must keep capital buffers against unexpected losses. Capital limits should be set to ensure a sufficient stability to protect holders of the bank's senior debt, bank customers, and shareholders and to support on-going business also in severe times by keeping a comfort buffer over legal requirements. The bank's internal capital assessment should combine the perspectives of legal requirements, market expectations, and economic capital. In addition to regulatory capital models as defined in pillar I of Basel II, banks should develop internal models which gives a more precise and risk-sensitive measure for internal capital assessment. Allocation of capital to business units should be an integral part of the regular planning process of banks. The analysis should be based upon actual and planned business volumes and risk development

Banks should use both stress testing and back testing at all levels of its business, from the assessment of the risk of individual credit deals to portfolios of credit risk, market risk and operations risk, and finally in assessing the adequacy of capital and liquidity. The macroeconomic environment is a major driver of risk to the bank's earnings and financial 
stability. Banks should regularly perform different stress tests on group- and branch level, based on specific historical (for example 1 in 10 or 1 in 50 years) or hypothetical scenarios and based on adverse economic conditions.

Stress testing and back testing forms an important part of bank's long-term capital adequacy assessment process and is an essential input to potential earnings volatility and capital and liquidity planning. Potential losses and the effect on available capital should be evaluated together with the effect of a scenario on the level of risk weighted assets (RWA). The stressed available capital is then compared with the RWA, under both internal and regulatory capital rules, to assess the bank's financial strength under much worse conditions than assumed in the business plan. Similarly, liquidity risk is regularly stressed to test the Bank's ability to withstand externally generated liquidity squeezes. The board of directors and other responsible committees should play a participatory and active role in risk and capital management. The capital of the bank should be defined in terms of both regulatory and economic in order to ensure that all risks are captured in the capital model and to protect both the depositors and the investors. In order to understand the financial consequences of business decisions on all levels and how they affect shareholder value over time, banks should proactively manage three main aspects: (1) the growth, mix and risk of business volumes, (2) capital, funding and liquidity requirements driven by the business and (3) profitability. Targets should be set and reviewed on a regular basis to manage and optimize resources in respect of these three aspects. Risks should only be taken where banks have the ability to understand, evaluate and manage the outcomes within the regulatory and economic capital limits

\section{References}

[1] Twesige D. Mwirumubi, R. and Mugerwa, E. (2016) Internal Capital Requirement and Performance of banking sector in Uganda: A case study of private commercial banks Journal of finance: Research Journal 6 (11), 2249-2490.

[2] Serge Piabuo Mandiefe (2016) How Working Capital Affects the Profitability of Commercial Banks: Case of Afriland Cameroon, Arabian Journal of Business and Management Review.

[3] Matten, C. (2001): Managing Banking Capital, Capital Allocation and Performance Measurement: Wiley New York.

[4] Basel Committee on Banking Supervision (2009): Range of practices and issues in economic capital frameworks.
[5] James R. Barth and Stephen Matteo Miller (2018) The Rising Complexity of Bank Regulatory Capital Requirements: From Global Guidelines to their United States (US) Implementation, Journal of Risk and Financial Management.

[6] Basel Committee on Banking Supervision (2004): International Convergence of Capital Measurement and Capital Standards: A Revised Framework. Bank for Basel Committee on Banking Supervision Basel.

[7] Grant, C. \& Osanloo, A. (2014). Understanding, Selecting, and Integrating a Theoretical Framework in Dissertation Research: Creating the Blueprint for 'House'. Administrative Issues Journal: Connecting Education, Practice and Research, Pp. 12-22 DOI: 10.5929/2014.4.2.9 1.

[8] Basel Committee on Banking Supervision (2003): The New Basel Capital Accord, Consultative Document. Basel Committee on Banking Supervision Basel.

[9] FSI (2016): "Literature review on integration of regulatory capital and liquidity instruments", BCBS Working Papers, no 30, March.

[10] Basel Committee on Banking Supervision (2016). Standardised measurement approach for operational risk. Bank for International Settlements.

[11] https://www.risk.net>definition>internal-ratings-based-irbapproach.

[12] Bank of Japan (2009): Economic Capital Workshop Summary Record, Http://Www.boj.or

[13] KPMG (2011): Basel III Issues and Implication. KPMG,

[14] https://www.bis.org $>$ fsi $>$ fsisummaries $>$ nfsr

[15] BCBS 2010: https://www.bis.org

[16] Tobias Beck (2010): A Market Model Approach for Measuring Counterparty Credit Risk of Interest Rate Derivatives,

[17] Kasomo, D. (2006): Research Methods in Humanities: $\left(1^{\text {st }}\right.$ Ed): Egerton University Press Publishers.

[18] Mugenda, A. (2013). Qualitative research methods: introduction. (1st ed.). Nairobi: Applied Research \& Training Services (ARTS Press).

[19] TAHERDOOST, H. (2016). Sampling Methods in Research Methodology; How to Choose a Sampling Technique for Research. International Journal of Advance Research in Management, 5 (2), 18-27.

[20] Krejcie, R. V., \& Morgan, D. W. (1970). Determining Sample Size for Research Activities. Educational and Psychological Measurement, 30, 607-610. 